UDC 624.014.2

\title{
COMPARATIVE ANALYSIS OF DESIGN SOLUTIONS OF METAL SILOS
}

\author{
Pichugin Sergii $^{1}$, Oksenenko Kateryna ${ }^{2 *}$ \\ ${ }^{1}$ Poltava National Technical Yuri Kondratyuk University https://orcid.org/0000-0001-8505-2130 \\ ${ }^{2}$ Poltava National Technical Yuri Kondratyuk University https://orcid.org/0000-0002-5171-3583 \\ *Corresponding author E-mail: shvadchenkokate@gmail.com
}

\begin{abstract}
Concept of bulk material and complexity of storing it are explained. The dependence between the physical and mechanical properties of the loose material and type of construction in which it is stored. Structural elements considered silos and silos with conical and flat bottom are described. The common characteristics of metal silos for bulk materials are given. The classification of metal silos by type of housing design is given. The advantages and disadvantages of silos are described. The possibility of storage of bulk materials in cylindrical shells is analyzed depending on the type of construction. The history of occurrence of structures of spiral-fold silos is considered. The set of equipment for the construction of the housing of the spiral-fold silos is given, the step-by-step process of formation of the folding lock and features of the installation process are presented. The analysis of the structure is made and the advantages and disadvantages of spiral-fold silos are determined.
\end{abstract}

Keywords: bulk material, steel silo, spiral-fold silo, folding lock

\section{ПОРІВНЯЛЬНИЙ АНАЛІЗ КОНСТРУКТИВНИХ РІШЕНЬ МЕТАЛЕВИХ СИЛОСІВ}

\author{
Пічугін С.Ф. ${ }^{1}$, Оксененко К.О. ${ }^{{ }^{*}}$ \\ ${ }^{1}$ Національний університет «Полтавська політехніка імені Юрія Кондратюка» \\ *Адреса для листування E-mail: shvadchenkokate@gmail
}

\begin{abstract}
Висвітлено поняття сипучого матеріалу, розглянуто дуальність сипучого матеріалу та пояснено складність його зберігання. Роз'яснено, що поведінка сипучої речовини підпорядковується різним закономірностям залежно від способу зберігання: у замкненому сосуді чи в умовно нескінченному просторі. Проаналізовано залежність між фізико-механічними властивостями сипучого матеріалу з типом конструкції, в якій він зберігається. Розглянуто поняття силосу, сферу його застосування та переваги використання порівняно з відкритими або закритими складами. Описано конструктивні елементи силосу: дах, корпус, дно. Проаналізовано силоси з конусним та плоским дном. Наведено загальні характеристики металевих силосів для сипучих матеріалів, їх класифікація за типом конструкції корпусу. Розглянутий кожен тип конструкції корпусу силосу, описано особливості їх монтажу. Проведено аналіз переваг та недоліків силосів, наведених у класифікації. Розглянуто можливість зберігання сипучих матеріалів у циліндричних оболонках залежно від типу конструкції. Вивчено історію виникнення конструкцій спірально-фальцевих силосів. Висвітлено можливість зберігання різних матеріалів у металевих силосах спірально-фальцевого типу. Приведено приклад елеватора зі спірально-фальцевими силосами, який експлуатується в Україні вже більше 40 років. Наведено комплект обладнання для зведення корпусу спірально-фальцевих силосів. Розглянуто основні функції кожного агрегату з комплекту обладнання. Описано поетапний процес утворення фальцевого замка й особливості процесу монтажу корпусу. Зроблено аналіз конструкції в цілому та визначено переваги і недоліки спірально-фальцевих силосів. На основі порівняльного аналізу обгрунтовано загальний висновок про перспективність застосування сталевих спірально-фальцевих силосів для сипучих матеріалів.
\end{abstract}

Ключові слова: сипучий матеріал, металевий силос, спірально-фальцевий силос, фальцевий замок. 


\section{Introduction}

Many modern technological processes are related to the processing of various bulk materials. In the chemical and metallurgical industries, as well as in the building materials industry, not only materials as coal, ore, gravel, sand, etc., are extracted, and in the process of processing primary raw materials produce a large number of new bulk materials such as coke, cement, slag, concentrates and others. It is also necessary to name an agroindustrial complex in with almost all products are bulk materials. A large number of granular materials makes it necessary to use a wide variety of machines, mechanical devices and structures for a faster and easier recycling process. One of the essential steps in the process - material storage. Ordinary composition of friable material is not a rational decision, as needs the considerable expenses of human labour for loading and unloading of material. The decision of this problem became silos for bulk materials.

\section{Review of the research sources and publications}

A large number of domestic and foreign scientists are in research of metal silos for bulk materials [1-2]. J. R. McCalmont was one of the first who classified silos and considered their characteristics [4]. Irena Selamovych and Robertas Balevichus considered in detail the analysis of the effect of rolling friction on the pressure distribution on the walls and velocities inside the fluid material [6]. Dietmar Schulz in his work examines general descriptions of friable solids, beginning from properties of stream of hard parts to behavior of stream of powders and friable materials in bunkers and silos. [7] G. L. Rozenblit in his work thoroughly examines rigid and flexible bunker for the coal industry [9]. V. V. Kachurenko thoroughly researched and described in his work behavioral and physical characteristics of the bulk material in silos [11]. D.O. Bannikov in his monograph presented authorial theoretical conception of co-operation of friable material with the elements of capacity building constructions [12]. A number of research in this area is increasing every year.

\section{Definition of unsolved aspects of the problem}

Nowadays there is quite a variety of types of bulk materials, the total number reaches several thousand. For their storage at different times concrete or metal welded silos were used $[1-10]$. Application of such types of constructions is related to difficult physical and mechanical properties of bulk materials. Such characteristics as tightness, strength and smooth surface of the wall made it possible to store a large variety of bulk materials.

Despite a large number of the works dedicated containers for bulk materials, some of which are listed above, almost all of them are focused on studies of metal silos for agriculture. Here are prefabricated silos with corrugated panels in bolted joints have proved best in our country and abroad. But the reliability of these structures are not fully investigated, it is confirmed by elevator accident associated with this type of construction.

\section{Problem statement}

The objective of this article is to review various structures of metal silos for bulk materials, the analysis of their advantages and disadvantages depending on the type of construction and method of installation.

\section{Basic material and results}

Before to begin the review of constructions of metallic silos, it is necessary to understand what it is a bulk material and what is the complexity of its storage.

Bulk materials is a material that has a pronounced grain structure with grain sizes, enabling flow of material in a confined space.

The specificity and complexity of storing bulk material is its duality. The bulk substance has properties inherent on one hand to continuous media (eg, the ability to exert pressure on vessel walls) and, on the other, to discrete media (eg, pressure dependence on material structure). Also the duality of granular substance is manifested in another respect. On the one hand bulk medium has properties of solids (eg, the ability to resist external forces) and at the same time, on the other hand, the properties of a liquid (such as the ability to flow or fill given volume).

It should also be borne in mind that the behavior of solids is subject to different laws depending on the method of storage, in a closed vessel or relatively infinite space. It is necessary to separately analyze static and dynamic behavior of granular material. After all, it is two rather different in nature phenomena that are associated with different structuring bulk material and therefore require the development of various theoretical models. Thus, in every case appear just quite different initial suppositions, as a result, eventual mathematical dependences quite often conduce to obvious contradictions.

Due to the features listed granular materials, it becomes clear the large number of types of metal structures silos. Fig. 1 shows the classification of metal silos for bulk materials. Consider it's each type in details.

General characteristics of silos. Silos are used to store a variety of bulk materials in various industries. Often, they are used in grain elevators, cement and coal depots, metallurgy and chemical industry. Silos can be storage for the raw materials, semi-finished and finished products and intermediate tanks in the process.

Widespread use of silage storages in different areas is explained by a number of advantages of storage of bulk materials in silos compared to storing them in bunkers and open or closed warehouses equipped with cranes. Silos are compact buildings, with a high payload ratio that allow for larger capacities in relatively small building areas. This significantly facilitates the placement of storages in master plan. 


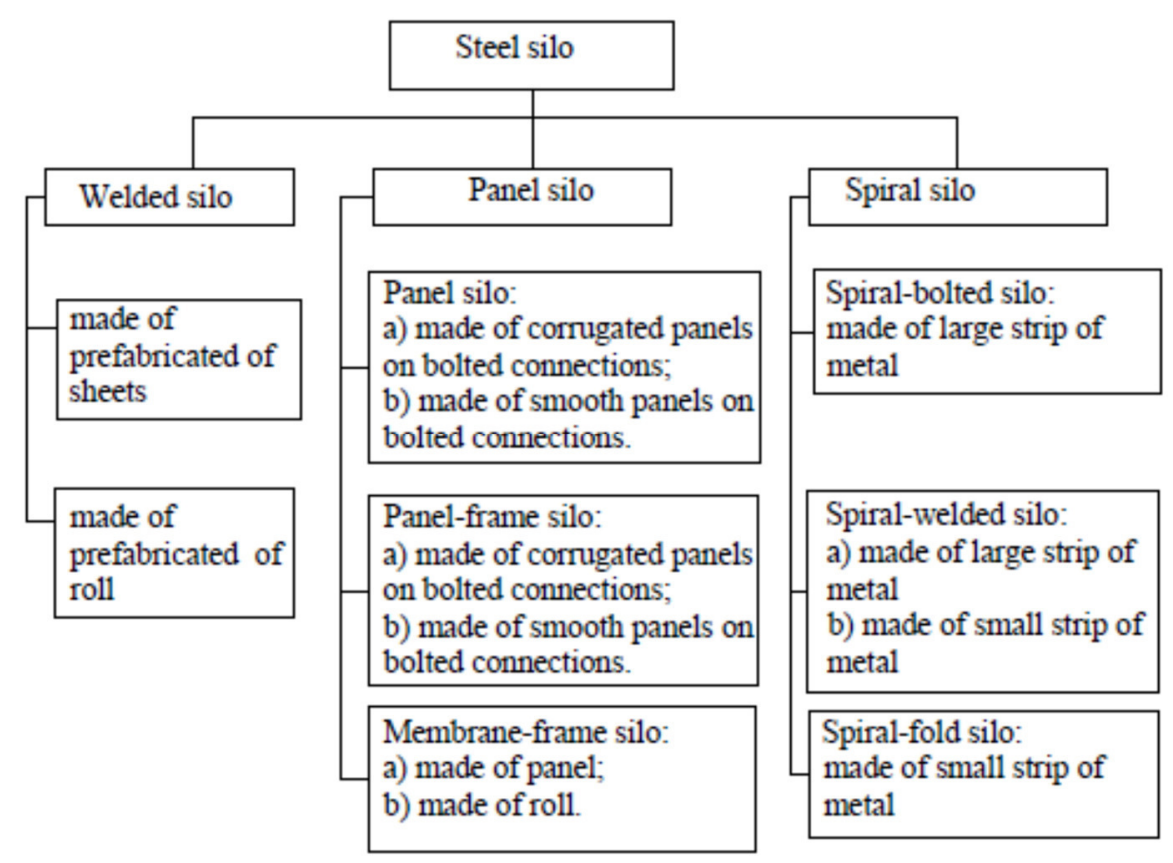

Figure 1 - Classification of metal silos

Thanks to the convenience of loading, unloading and high mechanical loading and unloading this type of closed storage facilities are the best in our time. Absence at the silos of free-surfaces, the methods of loading and unloading, that are used, provide reliable storage of materials and assist reduction of losses. In a silo there can be the organized drying of material that is kept, and also periodic moving for prevention of caking or spontaneous combustion.

Silo is a self-unloading capacitive structure in which the vertical height is 1.5 times greater than the diameter. For silos with a diameter of 18 meters or more, the ratio of the vertical part to the diameter may be smaller. The design is intended for long-term storage and overloading of bulk materials. Often, only the bearing capacity of the soil limits the height of the silos.

The main structural elements of the silo ar the roof, the housing, the bottom. The silo roof is a spatial conical structure, assembled from beam (rafters) and trapezoidal sectors. Trapezoidal roof sectors can have boxlike rib edges along the edges, which give greater rigidity to the structure and have better protection against atmospheric moisture. The roof accepts snow load and is intended to protect against falling into the capacity of the silo of precipitation. Housing is a cylindrical shell, the construction of which depends on the type of silo. There are silos with flat and conical bottoms (fig. 2).

Welded silos (fig. $3 \mathrm{a}, \mathrm{b}$ ) are a cylindrical shell, made of metal sheets welded together. According to the method of manufacture, these silos are divided into prefabricated sheets and rolls. The sheet silos are welded into a single housing made of individual sheets of metal. The roll silos are made of sheet metal, which is delivered to the construction site in the form of a roll whose height is equal to the height of the cylinder. During installation, the roll is positioned in a vertical position and unfolded around the perimeter of the annular foundation, forming a closed silo wall. The advantages of such silos are tightness and durability.

Due to this its are suitable for storage of various materials. Disadvantages of these structures are high material consumption and a large number of welds.

Panel silos (fig. 3 c) are a cylindrical shell is made of corrugated or smooth panels connected together with bolts. Corrugated panel profile helps save metal (due to thinner panels) and provides increased resistance to lateral load of silo. To compensate the loss of the bearing capacity of the panel through the corrugated profile on industrial silos establish additional ribs. The advantages of prefabricated silos are the opportunity to take large radial load on the material, no welds, high strength. The disadvantages of this option silos are a large number of bolted connections. This type of silo construction is most common in Ukraine and abroad, it is used in agriculture.

Panel-frame silos (fig. 3 d) have bent profile panels connected on bolts. In order to seal the silo, washers with gaskets are installed under the bolt heads. The roof of the silo is conical, it consists of annular and radial ribs, on which the flooring is arranged. The advantages of these silos are the strength and the absence of welded joints, the disadvantages are a large number of bolted connections, leaks, increased metal consumption and labor costs.

Membrane-frame silos [13] were developed at an institute in Moscow. The main structural element of these silos is a cylindrical membrane of membrane-frame type, made of tape $0.6-1 \mathrm{~mm}$ thick and $1250 \mathrm{~mm}$ wide. The tape is fastened in a spiral. The advantages of this option silos are covering membrane that takes only a tensile force, which allows full use calculated resistance; the disadvantages are large material consumption and complexity of installation. 
a)

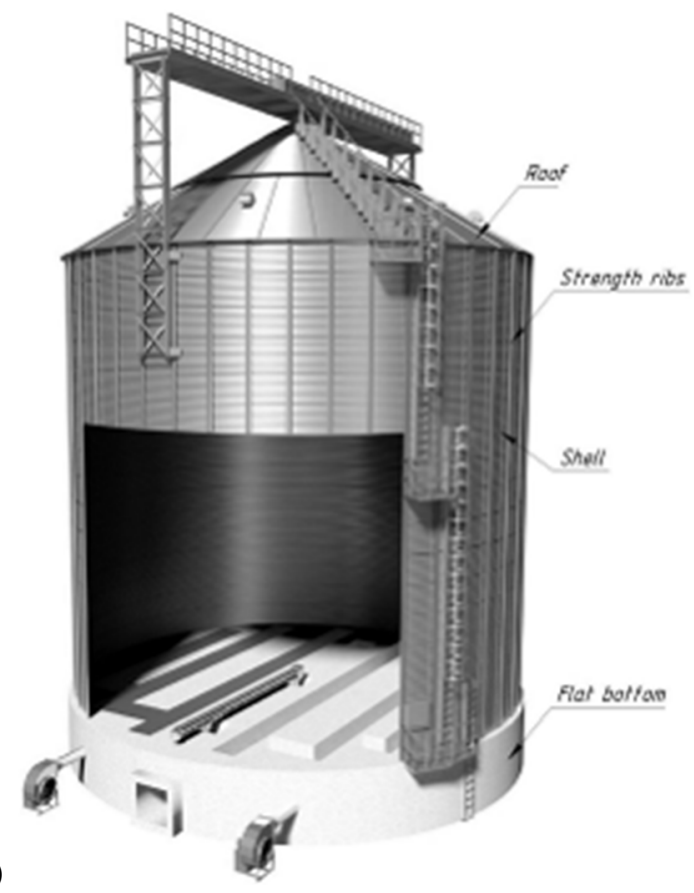

a)
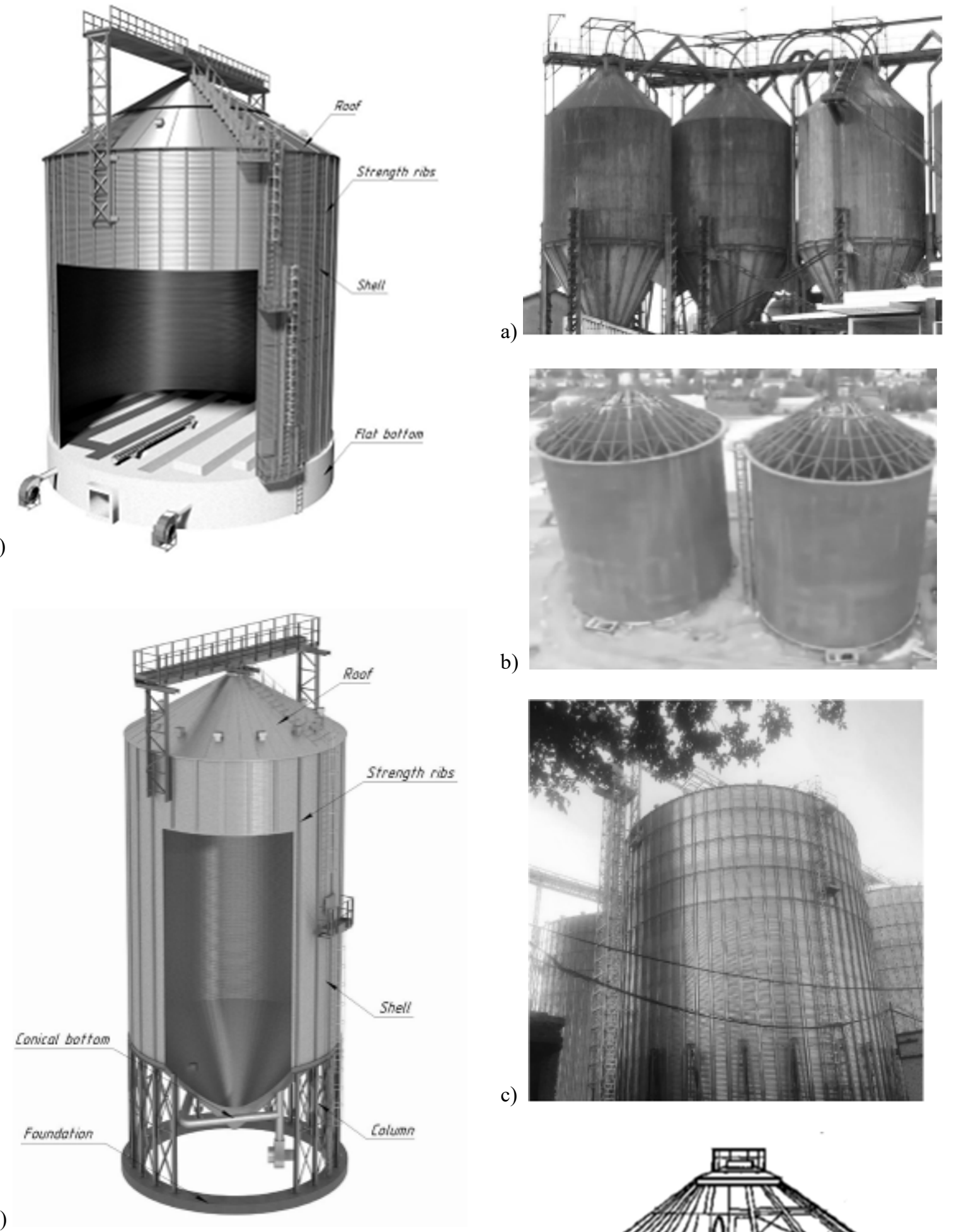

b)

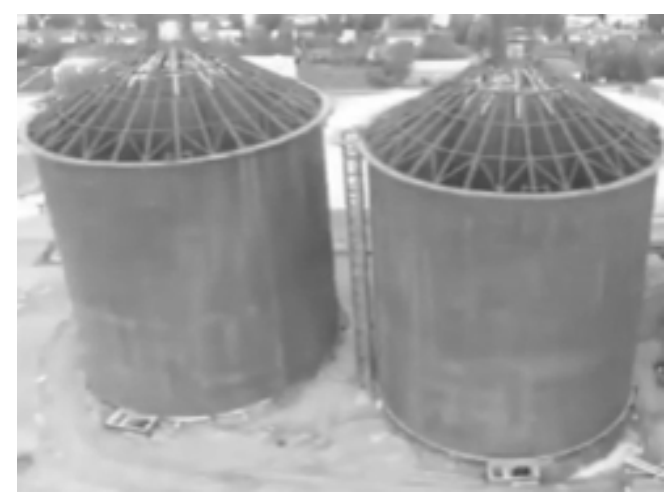

c)

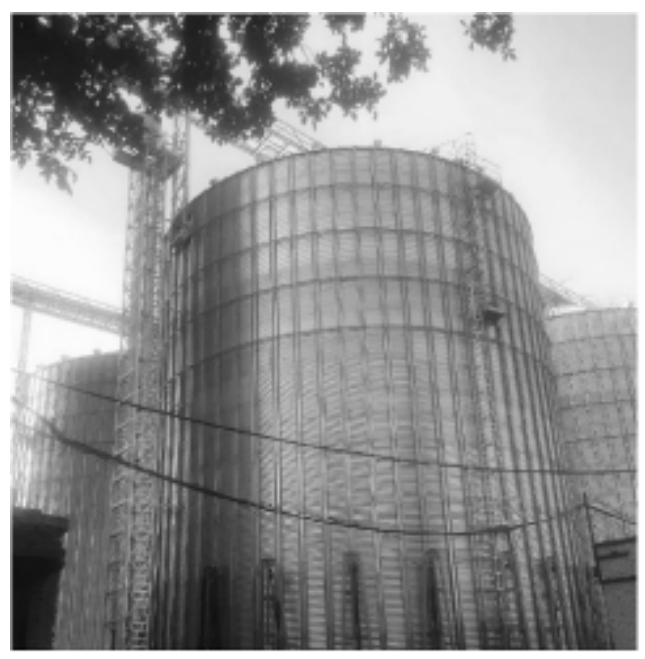

Figure 2 - Design elements of silo

a - silo with a flat bottom;

$\mathrm{b}$ - silo with conical bottom

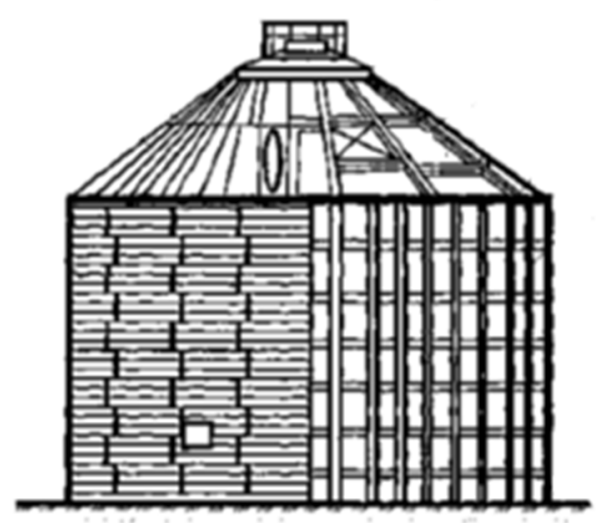

Figure 3 - Types of metal silos $\mathrm{a}, \mathrm{b}$ - welded silos;

$\mathrm{c}$ - panel silo; $\mathrm{d}$ - panel-frame silo 
Spiral-bolted silo (fig. 4 a) includes a cylindrical shell made of a metal ribbon, curved in a spiral, the edges of which are connected by an ascending rib (corner or channel) by means of fixed-pitch bolts. The advantages of such silos are the absence of welded joints, the strength, the absence of additional processing of the edge of the roll blanks and the rising edges for the molding of the housing; the disadvantages are special equipment required for housing formation, additional equipment for bending and mounting of rising ribs, drilling of large number of holes for mounting of bolts; additional vertical ribs must be installed to ensure wall reliability.

Spiral welded silo (fig. 4 b) has a cylindrical shell made of a metallic strip, curved in a spiral, the edges of which are joined by welding. Geometric rolled billet thickness $1-4 \mathrm{~mm}$, width $300-1250 \mathrm{~mm}$. The joint of the workpiece edge must be tight. The advantages of silo are strength and tightness, disadvantages - a large number of welds made on the site, for their quality performance requires additional processing of the edge.

a)
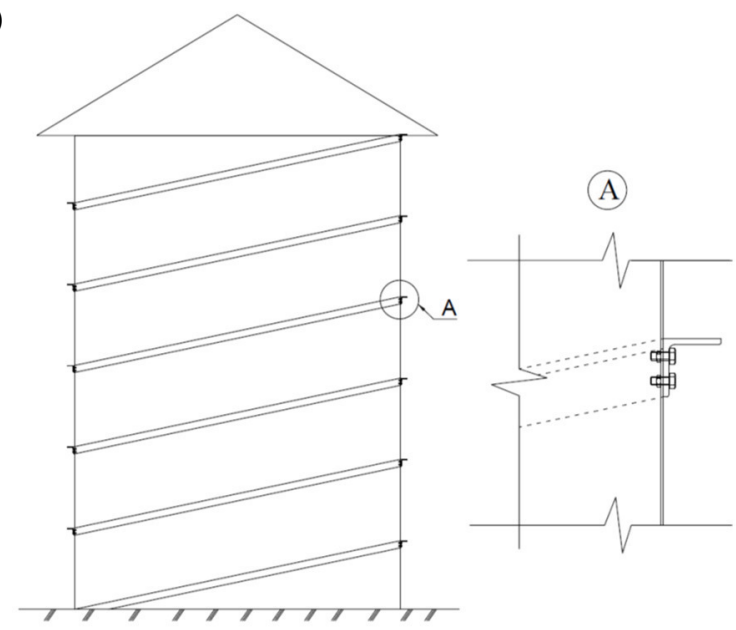

b)
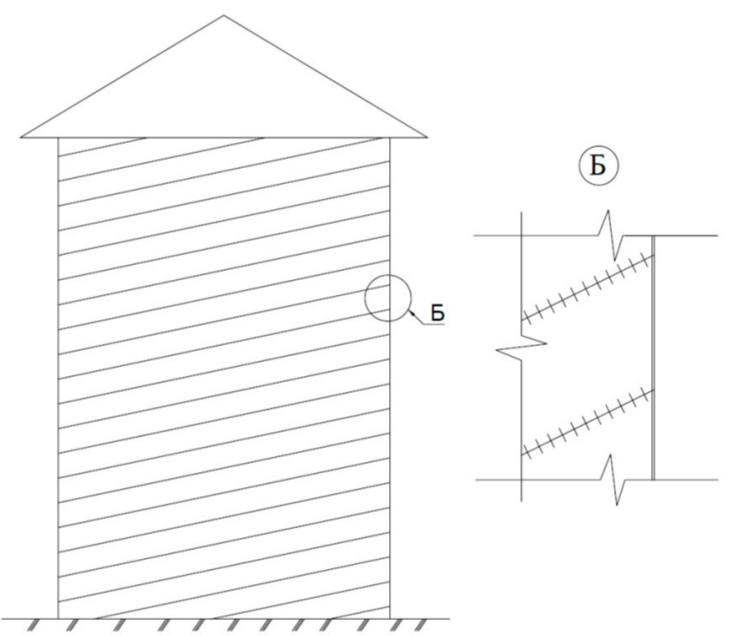

Figure 4 - Spiral silos:

$\mathrm{a}$ - the spiral-bolt; $\mathrm{b}$ - spiral welded
Spiral-fold silo (fig. 5) has a cylindrical body, which is a system of spiral connection of the steel strip by double folding. The design of the silo was developed in 1968 by a German scientist Xavier Lipp, who used the special equipment for processing of sheet metal and used it for the construction of silos spiral-fold [14]. The first silo was built in 1969 in Germany (fig. 5 a). Since the late 60 s in Europe they began using the silos with this type of construction. Within ten years of study and research, in practice, this technology has proved successful, and since the early 70's large-scale production of galvanized steel spiral-fold silos has began.

a)

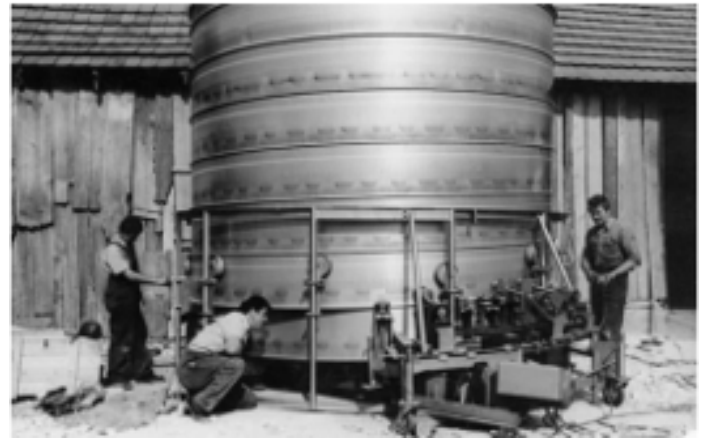

b)

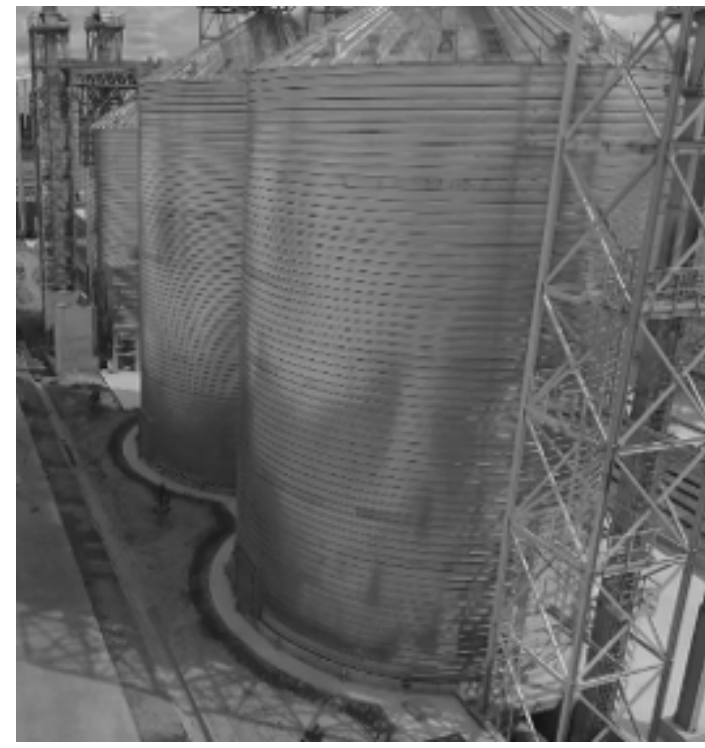

Figure 5 - Spiral-folded silos:

a - the first spiral-fold silo of Xaver Lipp, 1969;

b - spiral-fold silos (v. Korosten, Ukraine, 2018)

The advantages of these silos are:

- high precision, high degree of automation and speed of installation; reducing the time of installation and the required number of installers; minimizing the human factor in the installation, the whole process of silo installation is done automatically by a folding apparatus, the installation - from 4 to 6 days;

- when using the silo does not require any maintenance, can withstand a 7-point and larger earthquake, strong winds; warranty silo over 30 years; silo warranty for more than 30 years;

- good sealing, water resistance, complete absence of bolted connections and works related to waterproofing; 
with a long shelf life can install a steam system for safe storage of grain, it is possible to store waste water, oil, petroleum products, cement and other materials; when using stainless steel it is possible to store food; alcohol, wine, flour, malt, molasses, sunflower oil, etc;

- saving steel, high strength, high grade zinc from $275 \mathrm{~g} / \mathrm{m}^{2}$ to $450 \mathrm{~g} / \mathrm{m}^{2}$;

- silo cost 30\% lower then panel silos.

The disadvantages spiral-fold silos are:

- the maximum volume of silo may not exceed 10 thousand $\mathrm{m}^{3}$;

- for installation, the silo assembly equipment must be transported to the construction site, which increases the cost of production.

One of the first in Ukraine in Yemylivka village, $\mathrm{Ki}$ rovograd region in 1971 was commissioned the elevator with spiral-fold silos for storing grain (fig. 6). Despite its age, the company has been successfully operated to this day.

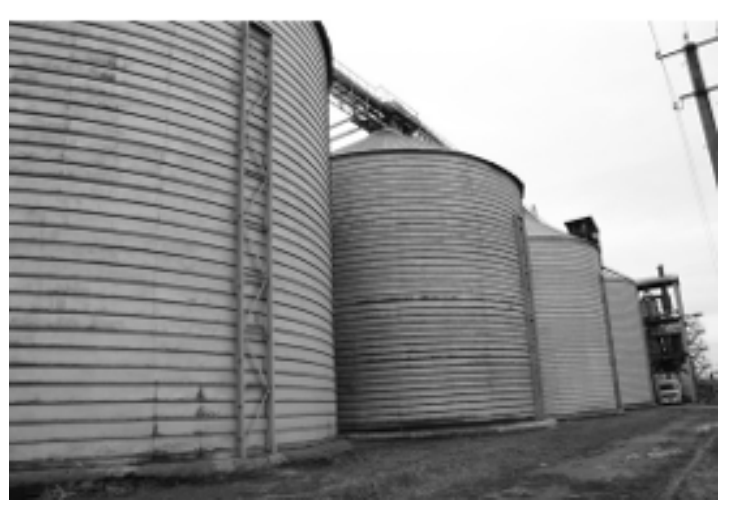

Figure 6 - Spiral-fold silos

(elevator in village Emylivka,

Kirovohrad region, 1971)

Technology of installation of spiral-fold silos. The set of equipment for the construction of spiral silo (fig. 7) consists of: the un-coiler reel, a profiling machine, a folding machine and a support frame.

The main function of the profilling machine is the profiling and bending of a steel strip $495 \mathrm{~mm}$ wide and $2-4 \mathrm{~mm}$ thick by the silo diameter.

The folding machine is intended for rolling of steel tape and at the same time creation of a strong rolled seam $30-40 \mathrm{~mm}$ wide with a total thickness of $11-32 \mathrm{~mm}$ from the outside of the silo, each turn of which gives an additional rib of rigidity of the whole structure.

The speed of installation of the silo's shell is $3-5 \mathrm{~m} / \mathrm{min}$.

The installation process consists of the following stages: a circle is deposited on the foundation which has equal diameter of silo and on the contour on the outside supporting frames and folding machine are mounted. Inside the silo, there is a un-coiler rell and a profiling machine. At the center of the foundation at the appropriate height set a metal ring to which the roof rafters will later be attached. The metal tape is introduced into the profiling machine and the folding machine and further in a circle with the help of supporting frames, the winding process takes place with the formation of a fold lock (fig. 8).

Unique technology allows for compact and fast installation of high-strength and hermetical silos directly at the construction site, without the use of bolts and welded joints.

a)

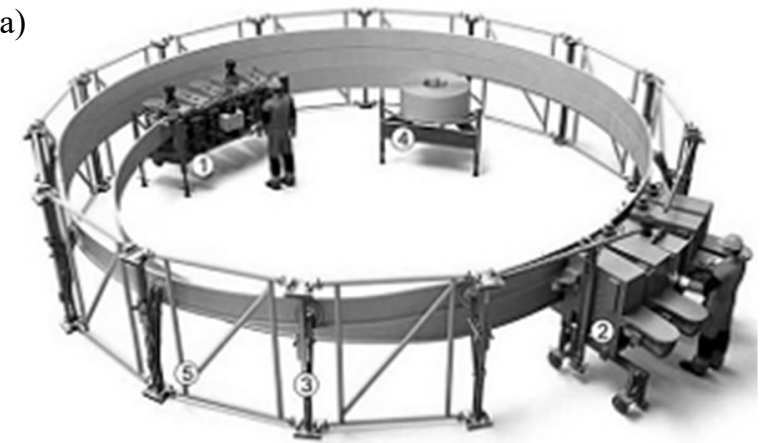

b)

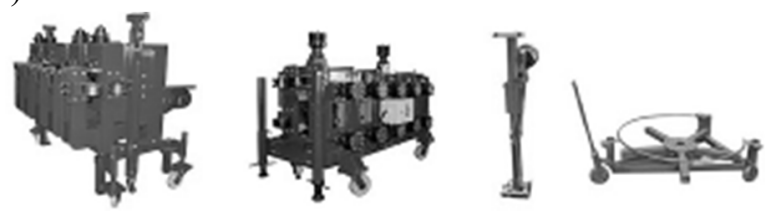

Figure 7 - Set of equipment for construction of spiral silo:

$\mathrm{a}-$ set of equipment in the working position, the process of coiling the silo's shell;

$\mathrm{b}$ - folding machine, profiling machine, support frame, un-coiler rell

a)

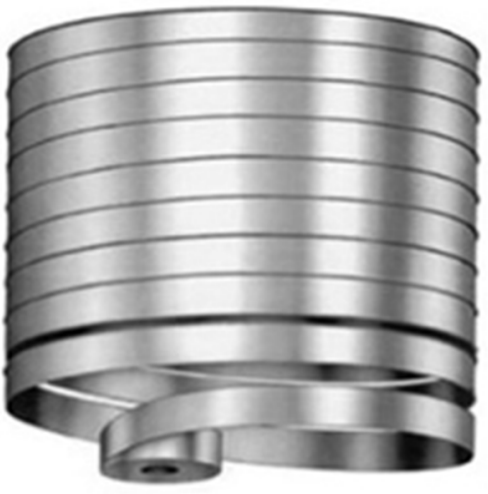

b)
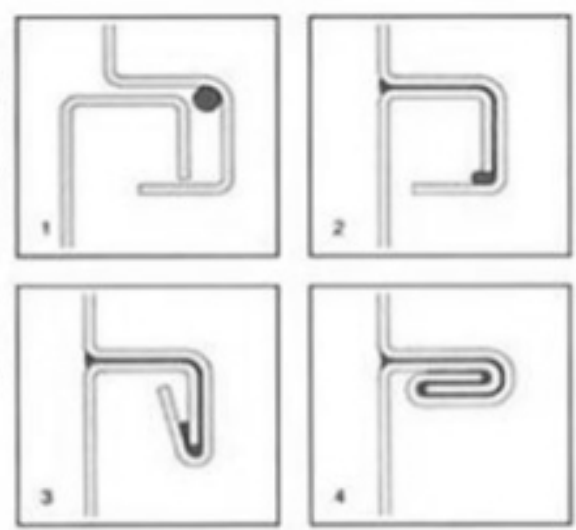

Figure 8 - The process of creating folding lock: a - spiral-fold shell;

$\mathrm{b}$ - phased process of creating a fold lock 


\section{Conclusions}

1. The physical and mechanical properties of bulk materials are analyzed.

2. The classification of metal silos for bulk materials is given.

3. The advantages and disadvantages of silos are considered, depending on the type of construction and method of installation.
4. Spiral-fold silos and method of their installation are discussed in detail.

On the basis of the comparative analysis, the general conclusion about the prospect of application of steel spiral-fold silos for bulk materials is substantiated.

\section{References}

1. Brown, C.J. \& Nielsen, J. (Ed.). 2011). Silos: Fundamentals of Theory, Behaviour. London and New York: E \&FN Spon.

2. Rotter, J.M. (2001). Guide for the Economic Design of Circular Metal Silos. CRC Press.

3. Elliott, M.D, Teh, L.H. \&Ahmed, A. (2019). Behaviour and strength of bolted connections failing in shear. Journal of Constructional Steel Research, 153, 320-329.

https://doi.org/10.1016/j.jcsr.2018.10.029

4. McCalmont, J.R. (1939). Silo types and construction. Washington: U.S. Dept. of Agriculture.

5. Thomson, F.M. (1997). Storage and Flow of Particulate Solids.

6. Sielamowicz, I., Balevicius, R. (2013). Exrerimental and computation analysis of granular material flow in model silos. Institute of Fundamental Technological Research Polish Academy of Sciences Exrerimental, Warsaw.

7. Schulze, D. (2009). Powders and Bulk Solids. Behavior, Characterization, Storage and Flow. Springer.

8. Демидов, С.В., Фисенко, А.С., Мыслин, В.А. и др. (1984). Архитектурное проектирование промышленных предприятий. Москва, Стройиздат.

9. Розенблит, Г.Л. (1953). Стальные конструкиии зданий и сооружений угольной промышленности. Москва: Углетехиздат.

10. Разумов, К.А., Петров, В.А. (1982). Проектирование обогатительных фабрик. Москва, Недра.

11. Качуренко, В.В., Банников, Д.О. (2016). Конструктивные решения стальных емкостей для сыпучих материалов. Днепропетровск, Новая идеология.

12. Банніков, Д.О. (2009). Сипучий матеріал в ємнісній конструкиії. Дніпропетровськ, Нова ідеологія.

13. Киселев, Б.Е. (1988). Цилиндрическая спиральнонавивная емкость мембранно-каркасного типа. Проектирование и строительство объектов агропромышленного комплекса. Серия: Строительные материаль и конструкции, здания и сооружения, 1, 29-30.

14. Xaver Lipp. Взято 3 https://xaver-lipp.com/
1. Brown, C.J. \& Nielsen, J. (Ed.). 2011). Silos: Fundamentals of Theory, Behaviour. London and New York: E \&FN Spon.

2. Rotter, J.M. (2001). Guide for the Economic Design of Circular Metal Silos. CRC Press.

3. Elliott, M.D, Teh, L.H. \&Ahmed, A. (2019). Behaviour and strength of bolted connections failing in shear. Journal of Constructional Steel Research, 153, 320-329.

https://doi.org/10.1016/j.jcsr.2018.10.029

4. McCalmont, J.R. (1939). Silo types and construction. Washington: U.S. Dept. of Agriculture.

5. Thomson, F.M. (1997). Storage and Flow of Particulate Solids.

6. Sielamowicz, I., Balevicius, R. (2013). Exrerimental and computation analysis of granular material flow in model silos. Institute of Fundamental Technological Research Polish Academy of Sciences Exrerimental, Warsaw.

7. Schulze, D. (2009). Powders and Bulk Solids. Behavior, Characterization, Storage and Flow. Springer.

8. Demidov, S.V., Fisenko, A.S., Myslin, V.A. and others (1984). Architectural design of industrial enterprises: Textbook for high schools. Moscow, Stroyizdat.

9. Rosenblit, G.L. (1953). Steel structures of buildings and structures of the coal industry. Moscow, Ugletekhizdat.

10. Razumov, K.A. (1982). Processing plants design: a textbook for universities. Moscow, Nedra.

11. Kachurenko, V.V., Bannikov, D.O. (2016). Constructive solutions of steel tanks for bulk materials. Dnepropetrovsk: New ideology.

12. Bannikov, D.O. (2009). Bulk material in Umnisny design. Dnepropetrovsk: Nova Ideology.

13. Kiselev, B.E. (1988). Cylindrical spiral-wound capacity of the membrane-frame type. Design and construction of agricultural facilities. Ser.: Building materials and structures, buildings and structures, 1, 29-30.

14. Xaver Lipp. Retrieved from https://xaver-lipp.com/ 